\title{
Biological products in association with organic matter to control Meloidogyne javanica in tomato
}

\author{
I. Hernandes, O.D. Costa Brito, A.P. Mendes Lopes, M.R. Cruz Soares and C.R. Dias-Arieira \\ Universidade Estadual de Maringá, Maringá, Brasil
}

\section{Summary}

Root-knot nematodes are responsible for significant tomato production losses and require taking integrated control measures. The aim of the current study is to evaluate the association between biological control and organic matter sources to Meloidogyne javanica control in tomato. In order to do so, two experiments were carried out under greenhouse conditions, in two different periods. Tomato plants were transplanted to pots and inoculated with 2,000 M. javanica eggs. Plants were treated with either Nem-Out ${ }^{\mathrm{TM}}$ or Compost-Aid ${ }^{\circledR}$ biological control products, which were individually applied or in association with organic wastes such as poultry litter, filter cake, rice hull and coffee hull. Nematological and vegetative parameters were evaluated 60 days later. The treatments, except for Nem-Out ${ }^{\mathrm{TM}}+$ poultry litter and Compost-Aid ${ }^{\circledR}+$ poultry litter, were efficient in reducing the number of galls. Treatment with Nem-Out ${ }^{\mathrm{TM}}$ + filter cake presented $83 \%$ gall reduction, whereas Compost-Aid ${ }^{\circledR}+$ filter cake presented $98.5 \%$ reduction. The associations between Nem-Out ${ }^{\mathrm{TM}}+$ poultry litter and Compost-Aid ${ }^{\circledR}+$ poultry litter did reduce the number of nematodes $\mathrm{g}^{-1}$ of root. Reduction in this parameter were observed for all others treatments, mainly when there was association between biological control (both, Nem-Out ${ }^{\mathrm{TM}}$ and Compost-Aid ${ }^{\circledR}$ ) and organic wastes; the treatment with Nem-Out ${ }^{\mathrm{TM}}+$ coffee hull reduced by $96 \%$ the number of nematodes $\mathrm{g}^{-1}$ of root, whereas the one with Compost-Aid ${ }^{\circledR}+$ filter cake reduced it by $97 \%$. Most of the treatments have positively influenced the vegetative variables in comparison to the inoculated control.

Keywords

Brazil, Lycopersicon esculentum Mill., biological control, integrated control, organic wastes, Meloidogyne javanica

\section{Introduction}

Tomato crop is an important vegetable production segment; however, it is limited by the action of nematodes, which compromise its production by up to $30 \%$ (Naika et al., 2006). Genus Meloidogyne is considered the most harmful nematode to tomato crops (Charchar and Aragão, 2005).

In the face of problems with the irregular use of agrochemicals, it is necessary to search efficient management alternatives compatible with the current environmental conservation and sustainability scenario in order to help mitigating damages caused by nematodes, as well as to assure safety to producers and consumers. Thus, the application of

\section{Significance of this study}

What is already known about this subject?

- The efficient nematode control results from the application of microorganisms and organic matter sources. Some studies have reported the successful association between these measures, which can work in several ways to maximize nematode control.

What are the new discoveries?

- The association between biological products and organic wastes was efficient in controlling Meloidogyne javanica in tomato plants, besides improving the vegetative parameters. The release of toxic substances during the waste decomposition process, in association with the action of microorganisms found in the tested products, may have negative effects on nematode populations, besides stimulating plant development.

What is the expected impact on horticulture?

- Results in the current study showed an efficient and sustainable nematode-control form, besides solving a waste-disposal issue.

microorganisms in the biological control of nematodes has been increasingly prioritized, since it is an effective measure capable of generating benefits to the crop without causing environmental impacts. Fungi and bacteria stand out among the most often used microorganisms, since they can control several nematode species in different crops (Alves et al., 2011; Kath et al., 2017; Silva et al., 2017).

Bacterial species belonging to genus Bacillus are considered important agents in the biological control of nematodes. These species can endophytically associate with plants, colonize the root tissues, mainly the rhizoplane, and help managing nematodes in different ways, namely, by producing toxic substances that compromise the nematode development or the location of the host, by promoting plant growth and by activating defense mechanisms in plants (Machado et al., 2012; Xiang et al., 2017). Besides bacteria, fungi such as Pochonia chlamydosporia (Goddard) Zare and Gams and Purpureocillium lilacinum (Thom) Luangsa-ard et al. have also been studied as important agents in the biological control of nematodes, acting in the reduction of juveniles and eggs (Silva et al., 2017; Dias-Arieira et al., 2018). In addition, fungi belonging to genus Trichoderma can reduce the number of nematodes through different action mechanisms such as direct parasitism, changes in the rhizosphere, enzyme activity and plant-resistance induction (Izuogu and Abiri, 2015; Zhang et al., 2015; Kath et al., 2017). Thus, bacteria and fun- 
gi play a key role in nematode control processes; both were proven to be effective against Meloidogyne spp., affecting different plant species such as tomato plants (Jamshidnejad et al., 2013; Al-Hazmi and Tariq-Javeed, 2016).

In addition to the biological control, the application of several organic wastes has shown satisfactory results in the reduction of nematode populations through the release of toxic substances, such as furfural, during the decomposition process (Bernardo et al., 2011; Crow and Luc, 2014 ), as well as through the release of nutrients such as nitrogen $(\mathrm{N})$, which may assist in the control of nematodes (Hassan et al., 2010), and silicon (Si), which is found in rice hulls and is responsible for increasing cell wall stiffness in the host and for inducing plant resistance to nematode penetration (Oliveira et al., 2012). Furthermore, organic wastes can act as substrate for microorganism development in the soil and lead to increased nematode-antagonistic populations (Absolusoro et al., 2013). Similar to biological control, the use of organic waste is environmentally friendly, provided it is properly applied.

The integration of different management practices helps optimizing the nematode control process, since these practices act on different lifecycle stages by hindering the parasitic activity and by favoring plant development. Thus, the association between biological control and different organic matter sources has the goal to maximize nematode control. It happens because organic wastes stimulate the growth of microorganism populations in the soil, thus favoring nematode control through competition, and increasing the number of predators and the production of secondary metabolites presenting nematicidal effects (Machado et al., 2012; Silva et al., 2016). Therefore, the aim of the current study was to assess the effect of commercial products based on fungi and bacteria, applied in association or not with different organic matter sources derived from plant and animal wastes, on the control of Meloidogyne javanica (Treub) Chitwood in tomato plants.

\section{Materials and methods}

The experiments were conducted in a greenhouse (geographic coordinates: latitude $23^{\circ} 25^{\prime} 31^{\prime \prime} \mathrm{S}$; longitude $51^{\circ} 56^{\prime} 19^{\prime \prime}$ W; altitude $596 \mathrm{~m}$ ) and followed a completely randomized design. Four experiments were carried out, with six or seven treatments (according to the controls) and five repetitions. They were performed from February to May 2017 (Experiment 1) and repeated between September and December 2017 (Experiment 2), at minimum and maximum temperatures $18^{\circ} \mathrm{C}$ and $34^{\circ} \mathrm{C}$, in the first period; and $20^{\circ} \mathrm{C}$ and $32.5^{\circ} \mathrm{C}$, in the second period, respectively.

Tomato seedlings cv. Santa Clara were initially prepared on polyethylene trays containing Plantmax ${ }^{\circledR}$ substrate. Fifteen days after germination, seedlings were transplanted to pots containing 1.6 L of substrate composed of soil and sand (1:1 ratio), which was previously autoclaved at $120^{\circ} \mathrm{C}$, for two hours.

Three days after transplantation, tomato plants were inoculated with 2,000 M. javanica eggs and second stage juveniles. The inoculum was obtained from a pure M. javanica population maintained in tomato and okra plants, under greenhouse conditions. The nematodes were extracted according to the methodology proposed by Hussey and Barker (1973), adapted by Boneti and Ferraz (1981). The inoculum was quantified under light microscopy (using counting slide) and calibrated for 2,000 eggs and eventual second stage juveniles (J2) in $2 \mathrm{~mL}$ of suspension. The inoculation was done by means of two holes of $2 \mathrm{~cm}$ deep opened in the soil around the plant. Plants remained in the pots for 40 days to enable nematode multiplication in order to simulate a naturally-infested soil condition.

Next, the shoot of the plants was discarded and treatments with organic wastes such as poultry litter, filter cake, coffee hull and rice hull (at the dose $3 \mathrm{t} \mathrm{ha}^{-1}$ ) were applied on the same day. The wastes were superficially incorporated to the soil. One sample of each waste was subjected to chemical composition analysis (Table 1).

Seven days later, a new tomato seedling cv. Santa Clara was transplanted into the pot and Nem-Out ${ }^{\mathrm{TM}}$ (Bacillus subtilis (Ehrenberg) Cohn, B. licheniformis (Weigmann) Chester and Trichoderma longibrachiatum Rifai; total microbiological count: $3.75 \times 10^{8} \mathrm{CFU} \mathrm{g}^{-1}$; protease, silanase and

TABLE 1. Chemical analysis applied to poultry litter, coffee hull, filter cake and rice hull.

\begin{tabular}{|c|c|c|c|c|c|}
\hline \multirow{2}{*}{ Parameters } & \multirow{2}{*}{ Unit } & \multicolumn{4}{|c|}{ Results } \\
\hline & & Poultry litter & Coffee hull & Rice hull & Filter cake \\
\hline Nitrogen (N) & $\mathrm{g} \mathrm{kg}^{-1}$ & 7.31 & 6.75 & 2.80 & 9.18 \\
\hline Phosphor (P) & $\mathrm{g} \mathrm{kg}^{-1}$ & 16.03 & 2.07 & 1.62 & 16.56 \\
\hline Potassium $\left(\mathrm{K}^{+}\right)$ & $\mathrm{g} \mathrm{kg}^{-1}$ & 51.36 & 45.03 & 3.14 & 18.17 \\
\hline Calcium $\left(\mathrm{Ca}^{2+}\right)$ & $\mathrm{g} \mathrm{kg}^{-1}$ & 113.99 & 49.29 & 0.62 & 112.99 \\
\hline Magnesium $\left(\mathrm{Mg}^{2+}\right)$ & $\mathrm{g} \mathrm{kg}^{-1}$ & 11.57 & 10.84 & 0.40 & 11.20 \\
\hline Sulfur (S) & $\mathrm{g} \mathrm{kg}^{-1}$ & 1.59 & 0.18 & 0.99 & 2.31 \\
\hline Iron $(\mathrm{Fe})$ & $\mathrm{g} \mathrm{kg}^{-1}$ & $2,361.89$ & 601.88 & 717.93 & $2,598.81$ \\
\hline Manganese (Mn) & $\mathrm{g} \mathrm{kg}^{-1}$ & $1,244.69$ & 119.04 & 300.00 & $1,433.17$ \\
\hline Copper (Cu) & $\mathrm{g} \mathrm{kg}^{-1}$ & 165.65 & 25.19 & 9.24 & 273.65 \\
\hline Zinc (Zn) & $\mathrm{g} \mathrm{kg}^{-1}$ & 423.79 & 32.56 & 13.48 & 321.98 \\
\hline Boron (B) & $\mathrm{g} \mathrm{kg}^{-1}$ & 116.57 & 92.60 & 23.77 & 79.56 \\
\hline Organic carbon & $\%$ & 20.01 & 55.39 & 47.33 & 23.96 \\
\hline Organic matter & $\%$ & 34.42 & 95.27 & 81.40 & 41.21 \\
\hline Ashes & $\%$ & 8.34 & 21.67 & 42.44 & 10.22 \\
\hline Moisture & $\%$ & 20.99 & 9.02 & 7.40 & 70.46 \\
\hline $\mathrm{pH} \mathrm{CaCl}{ }_{2}$ & & 8.86 & 6.84 & 5.30 & 6.48 \\
\hline C:N ratio & & $3: 1$ & $8: 1$ & $17: 1$ & $3: 1$ \\
\hline
\end{tabular}


cellulase- amounts were not reported by the manufacturer Improcrop ${ }^{\circledR}$ do Brasil Ltda.) or Compost-Aid ${ }^{\circledR}$ (Lactobacillus plantarum (Orla-Jensen), B. subtilis and Enterococcus faecium (Orla-Jensen), each presenting total microbiological count: $1.5 \times 10^{6} \mathrm{CFU} \mathrm{g}^{-1} ; 6.0 \%$ p:p cellulase, and $0.6 \%$ p:p amylase, Improcrop ${ }^{\circledR}$ do Brasil Ltda.) were applied at the dose $0.7 \mathrm{~g}$ of biological control product diluted in $5 \mathrm{~mL}$ of water (equivalent to $14 \mathrm{~kg} \mathrm{ha}^{-1}$ ). Treatments consisted of: NemOut $^{\mathrm{TM}} ; \mathrm{Nem}-\mathrm{Out}^{\mathrm{TM}}+$ poultry litter; Nem-Out ${ }^{\mathrm{TM}}+$ filter cake; Nem-Out ${ }^{\mathrm{TM}}+$ coffee hull; Nem-Out $^{\mathrm{TM}}+$ rice hull; inoculated control and non-inoculated control (for vegetative parameter comparison purposes). Similar treatments were applied with Compost-Aid ${ }^{\circledR}$. Twenty-eight days after transplantation, plants were once again subjected to the biological control, which was superficially applied to the soil; each one at the dose $0.15 \mathrm{~g}$ diluted in $5 \mathrm{~mL}$ of water. These experiments were named Nem-Out ${ }^{\mathrm{TM}}$-Exp. 1 and Nem-Out ${ }^{\mathrm{TM}}$-Exp. 2 or CompostAid $^{\circledR}$-Exp. 1 and Compost-Aid ${ }^{\circledR}$-Exp. 2, since they were conducted in two different periods, as it was previously mentioned.

After 60 days of the treatments, plants were removed from the pots to allow separating shoots from roots. Roots were carefully washed, deposited on absorbent paper to remove the excess of water, and the root fresh weight was determined. Next, the number of galls was assessed through direct counting and the roots were subjected to the nematode extraction method previously mentioned. Nematodes were quantified using counting slide under light microscopy. The total number of eggs $+\mathrm{J} 2$ was divided by the root weight in order to find the number of nematodes $\mathrm{g}^{-1}$ of root.

The plant shoot was used to assess parameters such as plant height, as well as shoot fresh and dry weights; the shoot dry weight was obtained after the shoot was dried in an oven under forced air circulation at $68^{\circ} \mathrm{C}$, for 72 hours.

Data were subjected to analysis of variance; significant means were compared through the Scott-Knott test in the Sisvar statistical software, at 5\% probability level (Ferreira, 2011). Data were transformed through $\sqrt{ }(x+0.5)$, whenever necessary, in order to meet normality assumptions.

\section{Results}

All treatments in Nem-Out ${ }^{\mathrm{TM}}$-Exp. 1 reduced the number of $M$. javanica galls in comparison to the control; Nem-Out ${ }^{\mathrm{TM}}+$ filter cake, Nem-Out ${ }^{\mathrm{TM}}+$ coffee hull, and Nem-Out ${ }^{\mathrm{TM}}+$ rice hull were the most efficient treatments (Table 2), since they showed $83 \%, 76.0 \%$ and $65.8 \%$ reduction in the number of galls, respectively, in comparison to the control. The treatments in Nem-Out ${ }^{\mathrm{TM}}$-Exp. 2, except for Nem-Out ${ }^{\mathrm{TM}}+$ poultry litter, presented reduction ranging from $37.2 \%\left(\mathrm{Nem}-\mathrm{Out}^{\mathrm{TM}}\right)$ to $90.8 \%$ (Nem-Out ${ }^{\mathrm{TM}}+$ filter cake). The number of nematodes $\mathrm{g}^{-1}$ of root was negatively influenced by all treatments in both experiments; reductions varied from $73 \%$ (NemOut $^{\mathrm{TM}}+$ filter cake) to $96 \%$ (Nem-Out $\mathrm{T}^{\mathrm{TM}}+$ coffee hull) in comparison to the control in Nem-Out ${ }^{\mathrm{TM}}$-Exp. 2 (Table 2).

The treatments increased tomato plant height in NemOut $^{\mathrm{TM}}$-Exp. 1; the highest increase (64\%) was recorded for $\mathrm{Nem}-\mathrm{Out}^{\mathrm{TM}}+$ filter cake, in comparison to the inoculated control (Table 3). Treatments in Nem-Out ${ }^{\mathrm{TM}}$-Exp. 2 were efficient in increasing such parameters, even when they were compared to the non-inoculated control. Treatments increased the root fresh weight in both experiments by 63\% (NemOut $^{\mathrm{TM}}$-Exp. 1) and 86\% (Nem-Out ${ }^{\mathrm{TM}}$-Exp. 2), when compared to the inoculated control. Similarly, the shoot fresh weight was higher in all treatments in the two experiments, except for Nem-Out ${ }^{\mathrm{TM}}+$ rice hull in Nem-Out ${ }^{\mathrm{TM}}$-Exp. 1. Treatments did not change the shoot dry weight in the first experiment; however, only Nem-Out ${ }^{\mathrm{TM}}$ and Nem-Out ${ }^{\mathrm{TM}}+$ rice hull did not differ from the inoculated control in the second experiment (Table 3).

Treatments in Compost-Aid ${ }^{\circledR}$-Exp. 1, except for Compost$\mathrm{Aid}^{\circledR}+$ poultry litter, were efficient in reducing the number of galls; the application of Compost-Aid ${ }^{\circledR}+$ filter cake reduced by $98 \%$ the number of galls in comparison to the control (Table 4). Similar results were found in Compost-Aid ${ }^{\circledR}{ }_{-}$ Exp. 2; however, Compost-Aid ${ }^{\circledR}+$ poultry litter increased the number of galls by $17 \%$. All treatments reduced the number of nematodes $\mathrm{g}^{-1}$ of root; the best result ( $97 \%$ reduction) was recorded for Compost-Aid ${ }^{\circledR}+$ filter cake, when it was compared to the control in the two experiments (Table 4).

TABLE 2. Number of galls and total number of Meloidogyne javanica nematodes per root gram in tomato plants treated with Nem-Out ${ }^{\mathrm{TM}}$ and different organic matter sources.

\begin{tabular}{|c|c|c|}
\hline Treatments & Galls & Nematode $\mathrm{g}^{-1}$ of root \\
\hline \multicolumn{3}{|c|}{ Nem-Out ${ }^{\mathrm{TM}}$-Exp. 1} \\
\hline Control inoculated & $529 a$ & $15,626 \mathrm{a}$ \\
\hline Nem-Out ${ }^{\mathrm{TM}}$ & $256 b$ & $1,405 b$ \\
\hline Nem-Out ${ }^{\mathrm{TM}}+$ poultry litter & $301 \mathrm{~b}$ & $4,209 b$ \\
\hline Nem-Out ${ }^{\mathrm{TM}}+$ coffee hull & $127 \mathrm{c}$ & $592 b$ \\
\hline Nem-Out ${ }^{T M}+$ rice hull & $181 \mathrm{c}$ & $2,958 \mathrm{~b}$ \\
\hline Nem-Out ${ }^{\mathrm{TM}}+$ filter cake & $90 \mathrm{c}$ & $2,245 b$ \\
\hline CV (\%) & 42.11 & 60.99 \\
\hline \multicolumn{3}{|c|}{ Nem-Out ${ }^{\mathrm{TM}}$-Exp. 2} \\
\hline Control inoculated & $196 \mathrm{a}$ & $10,087 \mathrm{a}$ \\
\hline Nem-Out ${ }^{\mathrm{TM}}$ & $123 b$ & $1,324 b$ \\
\hline Nem-Out ${ }^{\mathrm{TM}}+$ poultry litter & $179 a$ & $1,201 b$ \\
\hline Nem-Out ${ }^{\mathrm{TM}}+$ coffee hull & $23 c$ & $322 \mathrm{c}$ \\
\hline Nem-Out ${ }^{T M}+$ rice hull & $25 c$ & $591 \mathrm{c}$ \\
\hline Nem-Out ${ }^{\mathrm{TM}}+$ filter cake & $18 \mathrm{c}$ & $235 c$ \\
\hline CV (\%) & 19.89 & 31.85 \\
\hline
\end{tabular}

Within each experiment, means followed by the same letter in the column did not differ from each other in the Scott-Knott test, at $5 \%$ probability level. Original means were transformed through $\sqrt{ }(x+0.5)$ for statistical analysis purposes. $C V=$ coefficient of variation. 
TABLE 3. Height, root fresh weight, shoot fresh (SFW) and dry weights (SDW) of tomato plants treated with Nem-Out ${ }^{\mathrm{TM}}$, in association or not with organic wastes, and inoculated with Meloidogyne javanica.

\begin{tabular}{|c|c|c|c|c|}
\hline Treatments & Height (cm) & Root weight (g) & SFW (g) & $\operatorname{SDW}(g)$ \\
\hline & \multicolumn{4}{|c|}{ Nem-Out ${ }^{\text {TM }}$-Exp. 1} \\
\hline Control inoculated & $30.31 \mathrm{~d}$ & $2.87 \mathrm{C}$ & $11.39 \mathrm{~b}$ & $1.12^{\mathrm{ns}}$ \\
\hline Control not inoculated & $65.82 \mathrm{a}$ & $4.46 \mathrm{~b}$ & $26.03 \mathrm{a}$ & 2.52 \\
\hline Nem-Out ${ }^{\mathrm{TM}}$ & $30.86 \mathrm{~d}$ & $4.62 b$ & $17.33 \mathrm{a}$ & 1.71 \\
\hline Nem-Out ${ }^{\mathrm{TM}}+$ poultry litter & $44.45 \mathrm{c}$ & $7.79 \mathrm{a}$ & $21.79 a$ & 2.93 \\
\hline Nem-Out ${ }^{\mathrm{TM}}+$ coffee hull & $36.72 \mathrm{c}$ & $4.86 b$ & $21.59 a$ & 4.23 \\
\hline Nem-Out ${ }^{T M}+$ rice hull & $39.25 \mathrm{c}$ & $3.74 b$ & $13.61 b$ & 1.57 \\
\hline Nem-Out ${ }^{\mathrm{TM}}+$ filter cake & $49.83 b$ & $4.44 \mathrm{~b}$ & $21.66 \mathrm{a}$ & 2.49 \\
\hline \multirow[t]{2}{*}{ CV $(\%)$} & 13.68 & 22.02 & 18.23 & 29.85 \\
\hline & \multicolumn{4}{|c|}{ Nem-Out ${ }^{\mathrm{TM}}$-Exp. 2} \\
\hline Control inoculated & $25.28 d$ & $0.76 \mathrm{c}$ & $4.29 \mathrm{~d}$ & $0.60 \mathrm{c}$ \\
\hline Control not inoculated & $52.42 \mathrm{~b}$ & $5.02 \mathrm{a}$ & $15.03 b$ & $1.29 b$ \\
\hline Nem-Out ${ }^{\mathrm{TM}}$ & $42.42 \mathrm{c}$ & $3.97 b$ & $10.29 c$ & $1.01 \mathrm{c}$ \\
\hline Nem-Out ${ }^{\mathrm{TM}}+$ poultry litter & $61.42 \mathrm{a}$ & $5.79 a$ & $16.92 \mathrm{a}$ & $1.92 \mathrm{a}$ \\
\hline Nem-Out ${ }^{\mathrm{TM}}+$ coffee hull & $56.00 \mathrm{a}$ & $4.85 a$ & $15.27 b$ & $1.37 b$ \\
\hline Nem-Out ${ }^{T M}+$ rice hull & $49.42 b$ & $3.72 b$ & $13.13 b$ & $1.17 \mathrm{c}$ \\
\hline Nem-Out ${ }^{\mathrm{TM}}+$ filter cake & $60.57 \mathrm{a}$ & $5.42 \mathrm{a}$ & 16.87 a & $1.48 b$ \\
\hline CV (\%) & 12.86 & 18.28 & 14.75 & 35.87 \\
\hline
\end{tabular}

Within each experiment, means followed by the same letter in the column did not differ from each other in the Scott-Knott test, at $5 \%$ probability level. Original means were transformed through $\sqrt{ }(x+0.5)$ for statistical analysis purposes. $C V=$ coefficient of variation; ns = not significant.

TABLE 4. Number of galls and total number of Meloidogyne javanica nematodes per root gram in tomato plants treated with Compost-Aid ${ }^{\circledR}$ and different organic matter sources.

\begin{tabular}{|c|c|c|}
\hline Treatments & Galls & Nematode $\mathrm{g}^{-1}$ of root \\
\hline \multicolumn{3}{|c|}{ Compost-Aid $^{\circledR}$-Exp. 1} \\
\hline Control inoculated & $453 a$ & $97 \mathrm{a}$ \\
\hline Compost-Aid $^{\circledR}$ & $87 \mathrm{~b}$ & $36 \mathrm{~b}$ \\
\hline Compost-Aid $^{\circledast}+$ poultry litter & $565 a$ & $34 \mathrm{~b}$ \\
\hline Compost-Aid $^{\circledR}+$ coffee hull & $102 b$ & $17 \mathrm{c}$ \\
\hline Compost-Aid $^{\circledR}+$ rice hull & $56 \mathrm{~b}$ & $23 c$ \\
\hline Compost-Aid $^{\circledR}+$ filter cake & $7 \mathrm{~b}$ & $15 c$ \\
\hline \multirow[t]{2}{*}{ CV (\%) } & 84.15 & 32.86 \\
\hline & \multicolumn{2}{|c|}{ Compost-Aid $^{\circledR}$-Exp. 2} \\
\hline Control inoculated & $149 b$ & $7,537 \mathrm{a}$ \\
\hline Compost-Aid ${ }^{\circledR}$ & $41 \mathrm{~d}$ & 967 c \\
\hline Compost-Aid $^{\circledast}+$ poultry litter & $180 \mathrm{a}$ & $4,347 b$ \\
\hline Compost-Aid $^{\circledR}+$ coffee hull & $69 c$ & $1,369 c$ \\
\hline Compost-Aid ${ }^{\circledR}+$ rice hull & $25 \mathrm{e}$ & $485 \mathrm{c}$ \\
\hline Compost-Aid $^{\circledR}+$ filter cake & $4 f$ & $49 d$ \\
\hline CV $(\%)$ & 19.48 & 28.79 \\
\hline
\end{tabular}

Within each experiment, means followed by the same letter in the column did not differ from each other in the Scott-Knott test, at $5 \%$ probability level. Original means were transformed through $\sqrt{ }(x+0.5)$ for statistical analysis purposes. $C V=$ coefficient of variation.

Compost-Aid ${ }^{\circledR}+$ rice hull, Compost-Aid ${ }^{\circledR}+$ filter cake, and Compost-Aid ${ }^{\circledR}+$ poultry litter statistically differed from the inoculated control to plant height, increasing $65 \%$ in the treatment with Compost-Aid ${ }^{\circledR}+$ filter cake in Compost-Aid ${ }^{\circledR}$ Exp. 1. The other treatments did not present difference when they were compared to the inoculated control (Table 5). The application of Compost-Aid ${ }^{\circledR}$ alone did not differ from the inoculated control in Compost-Aid ${ }^{\circledR}$-Exp. 2. The best treatment was Compost-Aid ${ }^{\circledR}+$ filter cake, which increased plant height by $61 \%$ in comparison to the inoculated control and did not statistically differ from the non-inoculated control.

Treatments showed similar root fresh weight in Compost-Aid ${ }^{\circledR}$-Exp. 1 and did not differ from the inoculated and non-inoculated controls, except for Compost-Aid ${ }^{\circledR}+$ poultry litter, which increased the root fresh weight by $62 \%$ in comparison to the inoculated control (Table 5). All treatments in Compost-Aid ${ }^{\circledR}$-Exp. 2 increased this parameter and differed from the control, but not from each other. All treatments increased the shoot fresh weight in experiment 1 . Compost-Aid ${ }^{\circledR}+$ coffee hull did not differ from the inoculated con- 
TABLE 5. Height, root fresh weight, shoot fresh (SFW) and dry weights (SDW) of tomato plants treated with Compost-Aid ${ }^{\circledR}$, in association or not with organic wastes, and inoculated with Meloidogyne javanica.

\begin{tabular}{|c|c|c|c|c|}
\hline Treatments & Height $(\mathrm{cm})$ & Root weight (g) & SFW $(g)$ & SDW (g) \\
\hline & \multicolumn{4}{|c|}{ Compost-Aid ${ }^{\circledR}$-Exp. 1} \\
\hline Control inoculated & $33.36 \mathrm{~b}$ & $2.75 b$ & $11.36 \mathrm{~b}$ & $1.26 \mathrm{~b}$ \\
\hline Control not inoculated & $56.01 \mathrm{a}$ & $3.30 \mathrm{~b}$ & $20.91 \mathrm{a}$ & $2.07 \mathrm{~b}$ \\
\hline Compost-Aid $^{\circledR}$ & $41.33 b$ & $5.02 b$ & $18.10 \mathrm{a}$ & $2.28 \mathrm{~b}$ \\
\hline Compost-Aid ${ }^{\circledast}+$ poultry litter & $48.32 \mathrm{a}$ & $8.20 \mathrm{a}$ & $24.29 a$ & $3.31 \mathrm{a}$ \\
\hline Compost-Aid $^{\circledR}+$ coffee hull & $34.35 b$ & $4.39 \mathrm{~b}$ & $19.14 \mathrm{a}$ & $2.11 \mathrm{~b}$ \\
\hline Compost-Aid $^{\circledR}+$ rice hull & $48.91 \mathrm{a}$ & $4.00 \mathrm{~b}$ & $19.04 \mathrm{a}$ & $2.08 \mathrm{~b}$ \\
\hline Compost-Aid $^{\circledR}+$ filter cake & $50.93 \mathrm{a}$ & $3.47 b$ & $19.36 \mathrm{a}$ & $2.28 \mathrm{~b}$ \\
\hline \multirow[t]{2}{*}{ CV (\%) } & 18.53 & 38.66 & 23.33 & 28.85 \\
\hline & \multicolumn{4}{|c|}{ Compost-Aid ${ }^{\circledR}$-Exp. 2} \\
\hline Control inoculated & $38.14 \mathrm{e}$ & $1.83 \mathrm{~b}$ & $9.06 \mathrm{c}$ & $0.73 c$ \\
\hline Control not inoculated & $65.00 \mathrm{a}$ & $4.59 \mathrm{a}$ & $17.77 \mathrm{a}$ & $2.45 \mathrm{a}$ \\
\hline Compost-Aid $^{\circledR}$ & $39.85 \mathrm{e}$ & $3.93 \mathrm{a}$ & $10.06 \mathrm{c}$ & $0.96 \mathrm{c}$ \\
\hline Compost-Aid $^{\circledast}+$ poultry litter & $54.17 \mathrm{c}$ & $3.84 \mathrm{a}$ & $14.14 b$ & $1.63 b$ \\
\hline Compost-Aid $^{\circledR}+$ coffee hull & $44.14 \mathrm{~d}$ & $3.68 \mathrm{a}$ & $10.44 \mathrm{c}$ & $1.02 \mathrm{c}$ \\
\hline Compost-Aid $^{\circledR}+$ rice hull & $58.17 \mathrm{~b}$ & $4.26 \mathrm{a}$ & $15.60 \mathrm{~b}$ & $1.99 b$ \\
\hline Compost-Aid $^{\circledR}+$ filter cake & $62.14 \mathrm{a}$ & $7.87 \mathrm{a}$ & $17.37 \mathrm{a}$ & $2.31 \mathrm{a}$ \\
\hline CV (\%) & 7.02 & 27.61 & 11.88 & 25.45 \\
\hline
\end{tabular}

Within each experiment, means followed by the same letter in the column did not differ from each other in the Scott-Knott test, at $5 \%$ probability level. Original means were transformed through $\sqrt{ }(x+0.5)$ for statistical analysis purposes. $C V=$ coefficient of variation.

trol in experiment 2 , whereas the other treatments increased the shoot fresh weight by up to $52 \%$ in comparison to the inoculated control.

Treatment with Compost-Aid ${ }^{\circledR}+$ poultry litter showed the highest shoot dry weight in Compost-Aid ${ }^{\circledR}$-Exp. $1-38 \%$ increase in comparison to the inoculated control (Table 5). All treatments in the second experiment, except for Compost-Aid ${ }^{\circledR}$ and Compost-Aid ${ }^{\circledR}+$ coffee hull, were better than the inoculated control.

\section{Discussion}

The product based on B. licheniformis, B. subtilis, and T. longibrachiatum (Nem-Out ${ }^{\mathrm{TM}}$ ) reduced nematode multiplication, fact that was mainly evidenced by the lower number of galls and nematodes $\mathrm{g}^{-1}$ of root; such result corroborated the ones recorded for M. incognita (Kofoid and White) Chitwood in tomato plants (Silva et al., 2017), as well as for Pratylenchus brachyurus (Godfrey) Filipjev and Sch. Stekhoven and M. javanica in soybean plants (Miamoto et al., 2017). The efficiency of Trichoderma spp. in controlling nematodes was also reported in other pathosystems (Zhang et al., 2015; Kath et al., 2017). The potential of this fungal genus in controlling nematodes has been thoroughly investigated, mainly because it presents multiple action forms and interferes in different nematode lifecycle stages. Parasitism stands out among the aforementioned action forms; it inhibits the development of nematode eggs and juveniles, and this effect is related to increased chitinase and protease activity; to resistance induction through enzyme production; and to the production of toxic substances such as glucanases, chitinases, proteases, and lipases, which are capable of degrading the pathogen cell wall (Izuogu and Abiri, 2015; Kath et al., 2017).

Nem-Out $^{\mathrm{TM}}$ and Compost-Aid ${ }^{\circledR}$ (which was also efficient in controlling the nematode) present in their compositions the bacterium of the genus Bacillus, whose action on the nematodes has been widely confirmed (Alves et al., 2011; Hu et al.,
2017). Similar to the fungi Trichoderma, these bacteria use several action mechanisms such as the production of toxins that may have direct effect on nematodes and affect their reproduction, oviposition and hatching processes (Alves et al., 2011; Machado et al., 2012). They may also change the rhizosphere by modifying root exudates, and make nematodes become disoriented and unable to find the root system in host plants (Machado et al., 2012; Hu et al., 2017). In addition, several species and isolates belonging to the aforementioned bacterial genus are associated with pathogen-resistance induction in plants (Wei et al., 2014; Sharaf et al., 2016).

In addition to Bacillus, Compost-Aid ${ }^{\circledR}$ is composed of E. faecium and L. plantarum, which may act as accelerators in the organic matter decomposition process. Despite the limited number of studies about the use of Compost-Aid ${ }^{\circledR}$ to manage nematodes, there are reports about the efficiency of the product in controlling fungi (Bellotte et al., 2009; Nascimento et al., 2016).

The biological products applied alone were efficient in controlling the nematode; however, the nematode reduction was even greater when these products were applied in association with organic wastes, mainly with rice and coffee hulls and with filter cake, which overall controlled the number of nematodes per gram of root. These wastes may have helped controlling the nematode through direct action, since it has already been shown that the coffee hull decomposition process releases a substance called furfural, which has nematicidal action, besides providing the release of $\mathrm{NH}_{4}{ }^{+}$ions deriving from the waste (Bernardo et al., 2011; Crow and Luc, 2014), whose toxic effect on nematode species such as Meloidogyne arenaria (Neal) Chitwood, P. brachyurus, Heterodera glycines Ichinohe, and M. incognita (Rodríguez-Kábana et al., 1993; Bauske et al., 1994) was already confirmed. Furthermore, its effect can be attributed to the difficulty in recognizing host plants by nematodes (Bauske et al., 1994).

The rice hull, in its turn, presents high Si contents that, 
when absorbed by the plant, accumulate in the cell wall, increase its stiffness and form a mechanical barrier capable of preventing or delaying the pathogen penetration in the host tissues, thus making the plant more resistant (Oliveira et al., 2012; Mattei et al., 2017). Si can induce resistance in plants by affecting the reproductive capacity of nematodes, as it was demonstrated in the study involving coffee plants and Meloidogyne exigua (Goeldi), whose results were attributed to lignin production and/or to increased enzyme activity (Mattei et al., 2017). Application in natura of rice hulls promoted the reduction of M. javanica (Prakash and Singh, 2014), and the results can be attributed to changes in physical-chemical properties of the soil, such as increased alkalinity, electrical conductivity and many more metals.

The filter cake has also shown nematode control activity in different pathosystems (Youssef and El-Nagdi, 2010; Roldi et al., 2013); the effect on the nematode was due to the release of different nitrogen forms and to low $\mathrm{C}: \mathrm{N}$ ratio, since the $\mathrm{N}$ amount is related to the availability of organic matter in the soil, and such matter is responsible for nematode control (Hassan et al., 2010). The high $\mathrm{N}$ amount in the waste (Table 1) may have favored nematode-antagonistic populations such as fungi and bacteria, which, in their turn, enabled the nematode control through the production of enzymes and toxic substances (Howell, 2003; Kavitha et al., 2007).

The poultry litter was mainly efficient in reducing the number of nematodes $\mathrm{g}^{-1}$ of root. It may have happened due to its beneficial and stimulating action in fungal and bacterial populations applied to the soil via biological product (Absolusoro et al., 2013). In addition to the action in microorganisms, the control may be related to the action of toxic substances harmful to the nematode, such as humic and fulvic acids (Dias et al., 1999; Dias and Ferraz, 2001), which may have been released during the decomposition process. It may also be related to $\mathrm{N}$ release in the form of $\mathrm{NH}_{4}{ }^{+}$, which was available for plant uptake and had nematicidal action in eggs and juveniles (Akhtar and Malik, 2000) due to low C:N ratio in the waste (Table 1 ). In addition, the high $\mathrm{N}$ content in the waste can improve vegetative parameters and promote greater plant growth (Rodríguez-Kábana, 1986; Lima et al., 2011); such effect was observed in different plant-nematode associations (Lima et al., 2011; Abdel-Dayem et al., 2012; Fankam et al., 2014). The increased number of galls can be explained by the high $\mathrm{N}$ content, which may have contributed to the significant development of the root system in plants subjected to the treatment with poultry litter, thus resulting in increased number of new and tender roots; such outcome increased the availability of infection sites, as it was observed in other studies (Nazareno et al., 2010).

As it was already mentioned, besides the direct action of organic matters, they may have indirectly acted by stimulating the development of the biological control agents adopted in the current study, since the organic matter addition is a way to manipulate the environment and enable greater biological control efficiency by increasing the activity of nematode-antagonistic fungi and bacteria (Akhtar and Malik, 2000). The application of organic matter to the soil acts as nutrient source for these antagonists (Kerry, 1987) and the proliferation of these microorganisms may lead to increased enzyme activity and promote the accumulation of compounds with nematicidal action (Rodríguez-Kábana et al., 1987). In addition, despite having nematicidal effect, the biological control becomes more efficient, as well as presents fast and long-lasting action, when it is integrated with other control methods (Akhtar and Malik, 2000).
Regarding the availability of organic materials used in this study, they can be found in several regions of the country, being possible to obtain them in large quantities. For instance, rice hull is available mainly in the southern region of Brazil, due to the higher cereal production in this region (CONAB, 2018a). On the other hand, coffee hull is mainly found in the state of Minas Gerais, being the largest producer of coffee in the country, concentrating $50 \%$ of the production and processing, followed by Espírito Santo, São Paulo, Bahia, Rondônia and Paraná (CONAB, 2018b). Brazil is the largest producer of sugarcane in the world, producing a large quantity of filter cake, since each ton of processed cane generates $40 \mathrm{~kg}$ of filter cake, highlighting as major producers the Southeast and Central West regions (CONAB, 2017). In relation to poultry litter, the country is the second-largest producer of chicken in the world, producing 13.1 million tons in 2017, whose highest production comes from the South, mainly from the state of Paraná (ABPA, 2017).

The application of biological products and organic wastes has positively influenced most vegetative parameters assessed in all experiments when it was associated with Compost-Aid ${ }^{\circledR}$ and with Nem-Out ${ }^{\mathrm{TM}}$. The results can be due to the release of nutrients by the residues, since the organic matter promotes biostimulating effect through the release of several nutrients (Trevisan et al., 2010; Zandonadi et al., 2014) as well as the low C:N ratio. It enabled high $\mathrm{N}$ content, which was responsible for the increased plant height and root weight mainly observed after the application of filter cake and poultry litter, whose $\mathrm{C}: \mathrm{N}$ ratio was $3: 1$ (Table 1 ). Besides the $\mathrm{N}$, several other essential nutrients for the development of the plant were found in the organic amendments applied to the soil (Table 1). Although the herein applied organisms have effect on plant growth (Machado et al., 2015; Chagas et al., 2017), such effect was not observed in the present study when they were applied alone.

\section{Conclusion}

The association between organic wastes and biological products based on Bacillus spp. and Trichoderma sp. was efficient in reducing the Meloidogyne javanica population in tomato plants. Treatments with poultry litter and filter cake, applied in association with biological products, were the ones that most influenced the vegetative parameters of plants.

\section{References}

Abdel-Dayem, E.A., Erriquens, F., Verrastro, V., Sasanelli, N., Mondelli, D., and Cocozza, C. (2012). Nematicidal and fertilizing effects of chicken manure, fresh and composted olive mill wastes on organic melon. Helminthologia 49, 259-269. https://doi.org/10.2478/ s11687-012-0048-4.

ABPA - Associação Brasileira de Proteína Animal (2017). Relatório Anual 2017, p. 1-68.

Absolusoro, S.A., Absolusoro, P.F., Mathew, F.O., and Izuogu, N.B. (2013). Effects of organic and inorganic manures on the growth attributes of root-knot nematode (Meloidogyne incognita) infected Ethiopian eggplant (Solanum aethiopicum). World J. Agric. Res. 1, 104-107. https://doi.org/10.12691/wjar-1-6-2.

Akhtar, M., and Malik, A. (2000). Roles of organic soil amendments and soil organisms in the biological control of plant-parasitic nematodes: A review. Biores. Technol. 74, 35-47. https://doi. org/10.1016/S0960-8524(99)00154-6.

Al-Hazmi, A.S., and Tariq-Javeed, M. (2016). Effects of different inoculum densities of Trichoderma harzianum and Trichoderma 
viride against Meloidogyne javanica on tomato. Saudi J. Biolog. Sci. 23, 288-292. https://doi.org/10.1016/j.sjbs.2015.04.007.

Alves, G.C.S., Santos, J.M., Soares, P.L.M., Jesus, F.G., Almeida, E.J., and Thuler, R.T. (2011). Avaliação in vitro do efeito de rizobactérias sobre Meloidogyne incognita, M. javanica e Pratylenchus zeae. Arquivos do Instituto Biológico 78,557-564.

Bauske, E.M., Rodríguez-Kábana, R., Estáun, V., Kloepper, J.W., Robertson, D.G., Weaver, C.F., and King, P.S. (1994). Management of Meloidogyne incognita on cotton by use of botanical aromatic compounds. Nematropica 24, 143-150.

Bellotte, J.A.M., Kupper, K.C., Rinaldo, D., Souza, A., Pereira, F.D., and Goes, A. (2009). Acceleration of the decomposition of Sicilian lemon leaves as an auxiliary measure in the control of citrus black spot. Tropical Plant Pathol. 34, 71-76. https://doi.org/10.1590/S198256762009000200001.

Bernardo, J.T., Freitas, L.G., Yamada, J.K., Almeida, V.S., DallemoleGiaretta, R., and Ferraz, S. (2011). Efeito de adubos orgânicos sobre Meloidogyne javanica em tomateiro. Nematologia Brasil. 35, 1-10.

Boneti, J.I.S., and Ferraz, S. (1981). Modificações do método de Hussey \& Barker para extração de ovos de Meloidogyne exigua em raízes de cafeeiro. Fitopatologia Brasil. 6, 553.

Chagas, L.F.B., Chagas Junior, A.F., Soares, L.P., and Fidelis, R.R. (2017) Trichoderma na promoção do crescimento vegetal. Revista de Agric. Neotropic. 4, 97-102. https://doi.org/10.32404/rean.v4i3.1529.

Charchar, J.M., and Aragão, F.A.S. (2005). Reprodução de Meloidogyne spp. em cultivares de tomate e pepino sob estufa plástica e campo. Nematologia Brasil. 29, 243-249.

CONAB - Companhia Nacional de Abastecimento (2017). Acompanhamento da safra brasileira cana-de-açúcar 2017/2018, p. 1-66.

CONAB - Companhia Nacional de Abastecimento (2018a). Arroz Análise Mensal de Agosto de 2018, p. 1-11.

CONAB - Companhia Nacional de Abastecimento (2018b). Acompanhamento da safra brasileira café $2017 / 2018$, p. 1-88.

Crow, W.T., and Luc, J.E. (2014). Field efficacy of furfural as a nematicide on turf. J. Nematology $46,8-11$.

Dias, C.R., Ribeiro, R.C.F., Ferraz, S., and Vida, J.B. (1999). Efeito de frações de esterco bovino na eclosão de juvenis de Meloidogyne incognita. Nematologia Brasil. 23, 34-39.

Dias, C.R., and Ferraz, S. (2001). Efeito de frações biodigeridas de esterco de galinha sobre a eclosão e mortalidade de juvenis de Heterodera glycines. Nematologia Brasil. 25, 99-101.

Dias-Arieira, C.R., Araújo, F.G., Kaneko, L., and Santiago, D.C. (2018) Biological control of Pratylenchus brachyurus in soya bean crops J. Phytopathology 166(10), 722-728. https://doi.org/10.1111/ jph.12755.

Fankam, F., Sowley, E.N.K., and Oppong, N.E. (2014). Effect of poultry manure on the growth, yield and root-knot nematode (Meloidogyne spp.) infestation of carrot (Daucus carota L.). Arch. Phytopathol. and Plant Protection 48, 452-428. https://doi.org/10.1080/03235408. 2014.893639

Ferreira, D.F. (2011). Sisvar: a computer statistical analysis system. Ciência e Agrotecnologia 35, 1039-1042. https://doi.org/10.1590/ S1413-70542011000600001.

Ferreira, M.M.M., Ferreira, G.B., and Fontes, P.C.R. (2010). Eficiência da adubação nitrogenada do tomateiro em duas épocas de cultivo. Revista Ceres 57, 263-273. https://doi.org/10.1590/S0034737X2010000200019.

Hassan, M.A., Chindo, P.S., Marley, P.S., and Alegbejo, M.D. (2010). Management of root knot nematodes (Meloidogyne spp.) on tomato
(Solanum lycopersicum) using organic wastes in Zaria, Nigeria. Plant Protection Sci. 46, 34-38. https://doi.org/10.17221/1/2009-PPS.

Howell, C.R. (1997). Field control of cotton seedling diseases with Trichoderma virens in combination with fungicide seed treatments. J. Cotton Sci. 1, 15-20.

Hu, H.J., Chen, Y.L., Wang, Y.F., Tang, Y.Y., Chen, S.L., and Yan, S.Z. (2017). Endophytic Bacillus cereus effectively controls Meloidogyne incognita on tomato plants through rapid rhizosphere occupation and repellent action. Plant Disease 101, 448-455. https://doi. org/10.1094/PDIS-06-16-0871-RE.

Izuogu, N.B., and Abiri, T.O. (2015). Efficacy of Trichoderma harzianum T22 as a biocontrol agent against root-knot nematode (Meloidogyne incognita) on some soybean varieties. Croatian J. Food Sci. Technol. 7, 47-51. https://doi.org/10.17508/CJFST.2015.7.2.04.

Jamshidnejad, V., Sahebani, N., and Etebarian, H. (2013). Potential biocontrol activity of Arthrobotrys oligospora and Trichoderma harzianum BI against Meloidogyne javanica on tomato in the greenhouse and laboratory studies. Arch. Phytopathol. and Plant Protection 46, 1632-1640. https://doi.org/10.1080/03235408.20 13.778476.

Kath, J., Dias-Arieira, C.R., Ferreira, J.C.A., Homiak, J.A., Silva, C.R., and Cardoso, C.R. (2017). Control of Pratylenchus brachyurus in soybean with Trichoderma spp. and resistance inducers. J. Phytopathology 165, 1-9. https://doi.org/10.1111/jph.12619.

Kavitha, J., Jonathan, E.I., and Umamaheswari, R. (2007). Field application of Pseudomonas fluorescens, Bacillus subtilis and Trichoderma viride for the control of Meloidogyne incognita in sugarbeet. J. Biological Control 21, 211-215.

Kerry, B.R. (1987). Biological control. In Principles and Practice of Nematode Control in Crops, R.H. Brown, and B.R. Kerry, eds. (London, England: Academic Press), p. 253-263.

Lima, F.R., Campos, H.D., Ribeiro, L.M., Silva, L.H.C.P., Ribeiro, G.C., Neves, D.L., and Dias-Arieira, C.R. (2011). Efeito da cama de frango na redução da população do nematoide-de-cisto da soja. Nematologia Brasil. 35, 3-4.

Machado, D.F.M., Tavares, A.P., Lopes, S.J., and Silva, A.C.F. (2015). Trichoderma spp. na emergência e crescimento de mudas de cambará (Gochnatia polymorpha (Less.) Cabrera). Revista Árvore 39, 167-176. https://doi.org/10.1590/0100-67622015000100016.

Machado, V., Berlitz, D.L., Matsumura, A.T.S., Santin, R.C.M., Guimarães, A., Silva, M.E., and Fiuza, L.M. (2012). Bactérias como agentes de controle biológico contra fitonematóides. Oecologia Australis 16, 165-182. https://doi.org/10.4257/oeco.2012.1602.02.

Mattei, D., Dias-Arieira, C.R., Lopes, A.P.M., and Miamoto, A. (2017). Influence of Rocksil, Silifort and Wollastonite on penetration and development of Meloidogyne javanica in Poaceae and Fabaceae. J. Phytopathology 165, 91-97. https://doi.org/10.1111/jph.12540.

Miamoto, A., Silva, M.T.R.E., Dias-Arieira, C.R., and Puerari, H.H. (2017). Alternative products for Pratylenchus brachyurus and Meloidogyne javanica management in soya bean plants. J. Phytopathology 165, 635-640. https://doi.org/10.1111/jph.12602.

Naika, S., Jeude, J.V.L. de, Goffau, M. de, Hilmi, M., and Dam, B.V. (2006). A cultura do tomate: Produção, processamento e comercialização. Agrodok 17, 104 pp.

Nascimento, S.R.C., Silva, F.H.A., Cruz, B.L.S., Dantas, A.M.M., Ambrósio, M.M.Q., and Senhor, R.F. (2016). Sobrevivência de estrutura de resistência de Macrophomina phaseolina e Sclerotium rolfsii em solo tratado biologicamente. Revista Agroambiente On-line 10, 50-56. https://doi.org/10.18227/1982-8470ragro.v10i1.2947.

Nazareno, G.G., Junqueira, A.M.R., and Peixoto, J.R. (2010). Utilização de matéria orgânica para o controle de nematoides das galhas em alface sob cultivo protegido. Biosci. J. 26, 579-590. 
Oliveira, R.M., Ribeiro, R.C.F., Xavier, A.A., Pimenta, L., and Korndorfer, G.H. (2012). Efeito do silicato de cálcio e magnésio sobre a reprodução de Meloidogyne javanica e desenvolvimento de mudas de bananeira Prata-Anã. Rev. Brasil. de Fruticultura 34, 409-415. https://doi.org/10.1590/S0100-29452012000200013.

Prakash, J., and Singh, K. (2014). Impact of rice husk on population density and reproduction of tomato parasited root-knot nematodes. Eur. J. Biotechnol. Biosci. 2, 1-6

Rodríguez-Kábana, R. (1986). Organic and inorganic nitrogen amendments to soil as nematode suppressants. J. Nematology 18, 129-135.

Rodríguez-Kábana, R., Morgan-Jones, G., and Chet, I. (1987). Biological control of nematodes: Soil amendments and microbial antagonists. Plant and Soil 100, 237-247. https://doi.org/10.1007/ BF02370944.

Rodríguez-Kábana, R., Kloepper, J.W., Weaver, C.F., and Robertson, D.G. (1993). Control of plant parasitic nematodes with furfural A naturally occurring fumigant. Nematropica $23,63-73$.

Roldi, M., Dias-Arieira, C.R., Abe, V.H.F., Mattei, D., Severino, J.J., Rodrigues, D.B., and Felix, J.C. (2013). Agro-industrial waste and sewage sludge can control Pratylenchus brachyurus in maize. Acta Agric. Scandinavica, Section B - Soil and Plant Sci. 63, 283-287. https://doi.org/10.1080/09064710.2012.751449.

Sharaf, A.E.M.A., Kailla, A.M., Attia, M.S., and Nofal, M.M. (2016). Induced resistance in tomato plants against root knot nematode using biotic and abiotic inducers. Intl. J. Advanced Res. in Biolog. Sci. 3, 31-46. https://doi.org/10.22192/ijarbs.2016.03.11.004.

Silva, F.J., Ribeiro, R.C.F., Xavier, A.A., Santos Neto, J.A., Souza, M.A., and Dias-Arieira, C.R. (2016). Rizobactérias associadas a materiais orgânicos no controle de nematoides das galhas em tomateiro. Hortic. Brasil. 34, 59-65. https://doi.org/10.1590/S0102053620160000100009.

Silva, J.O., Santana, M.V., Freire, L.L., Ferreira, B.S., and Rocha, M.R. (2017). Biocontrol agents in the management of Meloidogyne incognita in tomato. Ciência Rural 47, 1-7. https://doi. org/10.1590/0103-8478cr20161053.

Wei, L., Shao, Y., Wan, J., Feng, H., Zhu, H., Huang, H., and Zhou, Y. (2014). Isolation and characterization of a rhizobacterial antagonist of root-knot nematodes. Plos One 9, 1-7. https://doi.org/10.1371/ journal.pone.0085988.

Xiang, N., Lawrence, K.S., Kloepper, J.W., Donald, P.A., and McInroy, J.A. (2017). Biological control of Meloidogyne incognita by spore-forming plant growth-promoting rhizobacteria on cotton. Plant Disease 101, 774-784. https://doi.org/10.1094/PDIS-09-16-1369-RE.

Youssef, M.M.A., and El-Nagdi, W.M.A. (2010). Effect of certain organic materials in controlling Meloidogyne incognita root-knot nematode infesting banana. Arch. Phytopathol. and Plant Protection 43, 660-665. https://doi.org/10.1080/03235400802021322.

Zhang, S., Gan, Y., and Xu, B. (2015). Biocontrol potential of a native species of Trichoderma longibrachiatum against Meloidogyne incognita. Appl. Soil Ecology 94, 21-29. https://doi.org/10.1016/j. apsoil.2015.04.010.

Received: May 10, 2018

Accepted: Nov. 28, 2019

Address of authors:

Isabela Hernandes, Olivia Diulen Costa Brito,

Ana Paula Mendes Lopes, Mayra Renata Cruz Soares and

Cláudia Regina Dias-Arieira

Universidade Estadual de Maringá, Maringá, Brasil 